\title{
Effect of a volumatic spacer and mouth rinsing on systemic absorption of inhaled corticosteroids from a metered dose inhaler and dry powder inhaler
}

Olof Selroos, Maija Halme

\begin{abstract}
Background High doses of inhaled corticosteroids are absorbed systemically and may cause long term side effects. As rinsing the mouth out after use and inhaling through a spacing device may reduce systemic absorption this has been further investigated.
\end{abstract}

Methods Three crossover studies were carried out to assess the effect of budesonide given by dry powder inhaler (Turbuhaler) with and without mouth rinsing and beclomethasone dipropionate given by metered dose inhaler with or without a spacing device (Volumatic) on serum cortisol concentrations and urinary cortisol excretion in patients with asthma taking an inhaled corticosteroid. Each treatment period was two weeks with a two week washout period. Serum cortisol concentrations at 0800 hours on day 14 and the 24 hour urinary excretion of cortisol were measured. In study 124 patients taking beclomethasone dipropionate 500 $\mu \mathrm{g}$ twice a day inhaled with $(n=10)$ or without $(n=14)$ a Volumatic spacing device were switched to a budesonide dry powder inhaler, $600 \mu \mathrm{g}$ to be taken twice a day without mouth rinsing. In study 210 patients took budesonide $800 \mu$ twice a day with and without mouth rinsing and without swallowing the rinsing water. In study 317 patients took budesonide $800 \mu \mathrm{g}$ twice daily with mouth rinsing and beclomethasone dipropionate $500 \mu \mathrm{g}$ twice daily with the spacing device and mouth rinsing.

Results In study 1 no difference was seen between budesonide without mouth rinsing and beclomethasone dipropionate without a spacer: beclomethasone with spacer caused less suppression of cortisol (mean (SD) serum cortisol concentration: beclomethasone and spacer 487(148), budesonide 368(145) $\mathrm{nmol} / \mathrm{l})$. In study 2 mouth rinsing caused less suppression of morning serum cortisol concentrations (rinsing 440(63), no rinsing 375(56) nmol/ 1). In study 3 there was no difference in serum or urinary cortisol concentrations between twice daily beclomethasone dipropionate $500 \mu \mathrm{g}$ inhaled by Volumatic spacer or budesonide by Turbuhaler 800 $\mu \mathrm{g}$ twice daily, both with mouth rinsing.
Individual serum cortisol values were within the normal range in all patients except one in study 1 .

Conclusion Systemic absorption of a corticosteroid inhaled from a metered dose inhaler is reduced by using a spacing device and that from a dry powder inhaler by mouth rinsing.

The development of glucocorticosteroids with low oral bioavailability, high local potency, and rapid biotransformation to metabolites with low glucocorticoid activity has improved the treatment of asthma. Although much less dangerous than equipotent doses of oral corticosteroids, high doses of inhaled corticosteroids have been reported to influence the hypothalamo-pituitary-adrenal axis. ${ }^{1-4}$

To minimise the risk of local side effects of inhaled corticosteroids, rinsing of the mouth is generally recommended after inhalation, though instructions about whether to spit out or swallow the rinsing water are often not given. Whether the water is swallowed may influence the systemic effects of inhaled corticosteroids. An alternative method of reducing local deposition of steroids from a metered dose inhaler is to use a large volume spacer, so that a substantial part of the actuated dose remains in the spacer. This has been shown to reduce the systemic effects of inhaled beclomethasone dipropionate, ${ }^{5}$ though conflicting results have been found with budesonide. ${ }^{67}$ Toogood et al ${ }^{6}$ reported increased suppression of the hypothalamo-pituitary-adrenal axis with the use of a spacer whereas Prahl and Jensen ${ }^{7}$ found decreased suppression.

The Turbuhaler is a breath actuated multidose inhaler that delivers budesonide without carrier powder, fluorocarbons, or lubricants. ${ }^{8}$ It cannot, however, be used with a spacer, so the dose inhaled by the patient may have a greater effect on the hypothalamo-pituitaryadrenal axis than the dose from a metered dose inhaler attached to a spacing device.

A series of investigations was carried out to determine the effect of a spacing device when beclomethasone dipropionate was taken from a metered dose inhaler and the effect of mouth rinsing when budesonide was inhaled from a dry powder inhaler, and to compare the systemic effects when the two drugs were inhaled under optimum conditions, beclomethasone by 
Table 1 Demographic data on asthma patients participating in the studies

\begin{tabular}{lllll}
\hline Study & $n$ & $\begin{array}{l}\text { Sex } \\
(M / F)\end{array}$ & $\begin{array}{l}\text { Age } \\
(y)\end{array}$ & $\begin{array}{l}\text { Mean }(S D) \\
F E V,(1)\end{array}$ \\
\hline $1 \mathrm{a}$ & 10 & $4 / 6$ & $43-68$ & $1 \cdot 7(0 \cdot 7)$ \\
$1 \mathrm{~b}$ & 14 & $7 / 7$ & $18-70$ & $2 \cdot 2(1 \cdot 0)$ \\
2 & 10 & $6 / 4$ & $34-62$ & $2 \cdot 4(0 \cdot 9)$ \\
3 & 17 & $7 / 10$ & $29-65$ & $1 \cdot 8(0 \cdot 8)$ \\
\hline
\end{tabular}

metered dose inhaler with a spacer and budesonide by dry powder inhaler with mouth rinsing.

\begin{abstract}
Methods
PATIENTS

Forty nine adults of either sex with asthma participated in the studies. Two patients participated in both study 1 and study 3 . Demographic data on the patients are shown in table 1 . None of the patients had any important hepatic or renal disease. All patients had been inhaling corticosteroid at a constant dose for at least three months before inclusion in a study.

In general, the patients had not been rinsing their mouth after inhaling the steroid. No recommendations had been given about what to do with the rinsing water. They received written information about the study and gave their informed consent. The study was conducted according to the Declaration of Helsinki (1975) and approved by the local ethics committee and the Finnish National Board of Health.
\end{abstract}

\section{STUDY DESIGN}

Study 1 All patients had used beclomethasone dipropionate $500 \mu \mathrm{g}$ twice daily for at least three months with $(n=10)$ or without $(n=14)$ a spacer. During the first two week study period they continued to take their medication as usual with or without a spacing device. They measured peak expiratory flow (PEF) in the morning and evening, and recorded asthma symptoms on a four point scale and their use of inhaled beta agonists. Serum cortisol concentration was determined on day 14 at 0800 hours, when the patients brought a 24 hour urine sample to the laboratory. This was collected from the morning of day 13 (with the first morning sample excluded) to the morning of day 14 (with the first morning sample included). Forced expiratory volume in one second $\left(\right.$ FEV $\left._{1}\right)$, forced vital capacity (FVC), and forced expiratory flow during $25-75 \%$ of vital capacity $\left(\mathrm{FEF}_{25-75}\right)$ were recorded (Vitalograph Compact, Vitalograph Ltd, Buckingham, UK). The patients were then given budesonide by Turbuhaler (Astra, Sweden), $600 \mu \mathrm{g}$ twice daily for four weeks. Diary card records were kept as before, but for the last two weeks only. At the end of the budesonide period spirometric and cortisol measurements were repeated at the same time of day as when they entered the study.

Study 2 In this study all patients took budesonide $800 \mu \mathrm{g}$ twice daily by Turbuhaler for two periods of two weeks separated by a two week washout period. They were asked during one period to rinse their mouth with a gulp of water after inhaling the steroid and to spit out the rinsing water and during the other period to take the steroid without rinsing the mouth; the order of the periods was randomised. During the washout period the patients used their inhaled steroid as usual without mouth rinsing. Serum cortisol values were determined on day 14 of the two week periods as in study 1 . No urine samples were collected and spirometric values, PEF, asthma symptoms, and use of beta agonists were not recorded.

Study 3 Patients who had been taking beclomethasone dipropionate $500 \mu \mathrm{g}$ twice daily with a spacer for at least three months and whose asthma was stable were included in this study. When the study started (period 1) they measured PEF in the morning and evening, and recorded their asthma symptom scores and use of inhaled beta agonists for two weeks while continuing the use of beclomethasone. On day 14 serum cortisol values were determined at $0800 \mathrm{~h}$ and 24 hour urinary cortisol samples collected as in study 1 . Spirometry was also carried out as in study 1 . Patients then changed to budesonide, inhaling $800 \mu \mathrm{g}$ twice daily by Turbuhaler for four weeks, and were asked to rinse their mouth after use and spit out the rinsing water. During the last two weeks of this four week period (period 2) the patients again recorded, as in period $1, \mathrm{PEF}$ in the morning and evening, symptom scores, and use of inhaled beta agonists. On day 14 spirometry was repeated and measurements of serum and urinary cortisol were made.

CORTISOL ASSAYS

All cortisol determinations were done by using the commercial radioimmunoassay kit Amerlex (Amersham International, Amersham, UK). The reference values obtained for healthy subjects are as follows: serum cortisol $280-830$ $\mathrm{nmol} / \mathrm{l}$, urinary cortisol 50-280 nmol/24 h.

\section{STATISTICAL ANALYSIS}

Geometric mean values, standard deviations, and $95 \%$ confidence intervals were calculated. Paired $t$ tests were used for comparing treatments. Differences were considered statistically significant if $p$ was $\mathbf{0 . 0 5}$ or less.

\section{Results}

STUDY 1

There were no differences in morning or evening PEF values, spirometric values (FVC, $\mathrm{FEV}_{1}, \mathrm{FEF}_{25-75}$ ), asthma symptom scores, or the use of extra puffs of an inhaled beta $a_{2}$ agonist (results not shown) after treatment with beclomethasone dipropionate or subsequent treatment with budesonide.

Serum cortisol values were within the normal range in all patients apart from one whose values were below the lower limit while taking both beclomethasone dipropionate and budesonide. There was no significant change in mean serum cortisol values for the 14 patients taking beclomethasone without a spacing device after they had changed to budesonide by Turbuhaler without mouth rinsing (table 2). For the 10 patients taking beclomethasone 
Table 2 Mean (SD) serum and urinary cortisol values in the three studies, with differences between mean values and 95\% confidence intervals (CI) of differences

\begin{tabular}{|c|c|c|c|c|c|c|c|c|}
\hline \multirow[b]{2}{*}{ Study } & \multirow[b]{2}{*}{$n$} & \multirow[b]{2}{*}{ Treatment } & \multicolumn{3}{|c|}{ Serum cortisol (nmol/l) } & \multicolumn{3}{|c|}{ Urinary cortisol ( $\mathrm{nmol} / 24 \mathrm{~h}$ ) } \\
\hline & & & $\operatorname{Mean}(S D)$ & $95 \% C I$ & $p$ & $\operatorname{Mean}(S D)$ & $95 \% C I$ & $p$ \\
\hline $1 \mathrm{a}$ & 10 & $\begin{array}{l}\text { BDP } 1.0 \mathrm{mg} \text { with spacer } \\
\text { BUD } 1.2 \mathrm{mg} \\
\text { Difference }\end{array}$ & $\begin{array}{l}487(148) \\
368(144) \\
119(94)\end{array}$ & $52-187$ & 0.003 & $\begin{array}{r}165(51) \\
113(52) \\
52(22)\end{array}$ & $37-68$ & $<0.001$ \\
\hline $1 b$ & 14 & $\begin{array}{l}\text { BDP } 1.0 \mathrm{mg} \text { without spacer } \\
\text { BUD } 1.2 \mathrm{mg} \\
\text { Difference }\end{array}$ & $\begin{array}{r}482(142) \\
474(101) \\
8(124)\end{array}$ & $-64-79$ & 0.819 & $\begin{array}{c}140(50) \\
164(110) \\
-\quad 25(94)\end{array}$ & $-79-30$ & 0.343 \\
\hline 2 & 10 & $\begin{array}{l}\text { BUD } 1.6 \mathrm{mg} \text { with mouth rinsing } \\
\text { BUD } 1.6 \mathrm{mg} \text { without mouth rinsing } \\
\text { Difference }\end{array}$ & $\begin{array}{r}440(63) \\
375(56) \\
65(58)\end{array}$ & 23-107 & 0.007 & $\stackrel{\star}{\star}$ & & \\
\hline 3 & 17 & $\begin{array}{l}\text { BDP } 1.0 \mathrm{mg} \text { with spacer and mouth rinsing } \\
\text { BUD } 1.6 \mathrm{mg} \text { with mouth rinsing } \\
\text { Difference }\end{array}$ & $\begin{array}{l}459(124) \\
453(68) \\
5.9(91)\end{array}$ & $-41-53$ & 0.792 & $\begin{array}{r}157(33) \\
149(30) \\
7(21)\end{array}$ & $-4-18$ & $0 \cdot 187$ \\
\hline
\end{tabular}

«Not measured.

BDP—beclomethasone dipropionate; BUD—budesonide by Turbuhaler.

dipropionate with a spacer cortisol concentrations were significantly higher than after they had changed to budesonide without mouth rinsing (table 2 ). These patients also had higher 24 hour urinary cortisol excretion when taking beclomethasone than when taking budesonide $(p<0.001)$. No change in urinary cortisol concentrations was seen in the patients changing from beclomethasone without a spacer to budesonide (table 2 ).

STUDY 2

Serum cortisol concentrations were significantly higher in patients taking bedesonide 800 $\mu \mathrm{g}$ twice a day when they rinsed their mouth after inhalation and spat out the water than after inhalation without mouth rinsing (table 2).

\section{STUDY 3}

There was no significant change in mean serum and urinary cortisol values for the 17 patients taking beclomethasone dipropionate $500 \mu \mathrm{g}$ twice a day with a spacing device (and mouth rinsing after inhalation) after they had changed to budesonide by Turbuhaler $800 \mu \mathrm{g}$ twice a day with mouth rinsing (table 2 ).

\section{Discussion}

Systemic side effects caused by inhaled corticosteroids must be due to absorption of steroids from the lungs, oropharyngeal cavity, or gastrointestinal tract.

The use of the $750 \mathrm{ml}$ Volumatic spacing device reduces oropharyngeal deposition because the particles stay in the spacer. Pulmonary deposition has been shown to increase from $8-10 \%$ to $15 \% . .^{9}$ Study 1 showed that beclomethasone dipropionate $500 \mu \mathrm{g}$ twice a day when inhaled via the spacer caused less reduction of plasma and urinary cortisol concentrations than did budesonide $600 \mu \mathrm{g}$ twice a day from a Turbuhaler. This difference suggests that the major influence of inhaled steroids on the hypothalamo-pituitary-adrenal axis is caused by the swallowed part of the inhaled dose and not by the dose deposited in the airways. These results are in agreement with those obtained in uncontrolled studies of patients by Prahl and Jensen ${ }^{7}$ and Brown et al and in a controlled study on healthy volunteers, who used beclomethasone dipropionate 2000 $\mu \mathrm{g}$ with or without a spacer. ${ }^{10}$

If the swallowed drug is important it is surprising that no difference in mean serum cortisol values was seen between patients taking beclomethasone dipropionate with a spacer and those taking it without a spacer in study 1 . This may reflect differences in serum cortisol between patients in the two groups due to other factors.

Mouth rinsing has usually been recommended to avoid oropharyngeal candidiasis, rather than as a protection against systemic side effects. If the swallowed part of the inhaled dose is important in determining systemic absorption, it is important to give patients instructions on what to do with the rinsing water. In study 2 patients were told clearly to rinse or not to rinse their mouth after inhalation and to spit out the rinsing water after rinsing. Plasma cortisol concentrations were significantly higher when the patients spat out the rinsing water.

We further tested the hypothesis that the swallowed dose is important in study 3 by comparing the best alternatives in 17 patientsthat is, beclomethasone dipropionate via the Volumatic and budesonide via the Turbuhaler with mouth rinsing and spitting out the rinse water. There was no significant difference in the concentration of plasma or urinary cortisol when the patients used beclomethasone dipropionate $500 \mu \mathrm{g}$ twice daily with a spacing device and mouth rinsing and budesonide 800 $\mu \mathrm{g}$ twice daily with mouth rinsing. The dose of budesonide was $60 \%$ higher than the dose of beclomethasone dipropionate. The two drugs had a similar effect on the cortisol concentrations, however, presumably because of the more rapid metabolism of budesonide. These results are in agreement with those of Löfdahl et al, ${ }^{11}$ who showed that the dose of budesonide could be $70 \%$ greater than the dose of beclomethasone dipropionate with the same plasma cortisol concentrations.

The results of these studies indicate that the swallowed part of an inhaled dose of glucocorticosteroids is important. This is presumaly because it contributes to the total bioavailability of the drug. To decrease the effect 
of inhaled corticosteroids on serum and urinary cortisol, and to avoid oropharyngeal candidiasis, patients using an inhaled corticosteroid without a spacing device should be advised to rinse their mouth after inhalation and to spit out the rinsing water. The higher the daily dose of the corticosteroid the more important this advice is.

We gratefully acknowledge the assistance of Mrs Ann-Britt Löfroos, clinical research assistant, in monitoring the studies and of Dr Tore Persson in giving statistical guidance.

1 Choo-Kang YFJ, Cooper EJ, Tribe AE, Grant IWB. Beclomethasone dipropionate by inhalation in the treatment of airways obstruction. Br J Dis Chest 1972;66: ment of

2 Gaddie J, Petrie GR, Reid IW, Sinclair DJM, Skinner C, Palmer KNV. Aerosol beclomethasone dipropionate: dose-response study in chronic bronchial asthma. Lancet 1973;ii:280-1.
3 Harris DM, Martin LE, Harrison C, Jack D. The effect of oral and inhaled beclomethasone dipropionate on adrenal function. Clin Allergy 1973;3:243-8.

4 Smith MJ, Hodson ME. Effects of long term inhaled high dose beclomethasone dipropionate on adrenal function. Thorax 1983;38:676-81.

5 Brown PH, Blundell G, Greening AP, Crompton GK. Do large volume spacer devices reduce the systemic effects of high dose inhaled corticosteroids? Thorax 1990;45:736-9.

6 Toogood JH, Jennings B, Baskerville J, Johansson S-A. Clinical use of spacer systems for corticosteroid inhalation therapy: a preliminary analysis. Eur J Respir Dis 1982; 63(suppl 122):100-7

7 Prahl $P$, Jensen $T$. Decreased adreno-cortical suppression utilising the Nebuhaler for inhalation of steroid aerosois. utilising the Nebuhaler for inh
Clin Allergy 1987;17:393-8.

8 Wetterlin $\mathrm{K}$ Turbuhaler: A new powder inhaler for adminWetterlin K. Turbuhaler: A new powder inhaler for admin-
istration of drugs to the airways. Pharmaceut Res 1988; 5:506-8.

9 Newman SP, Millar AB, Lennard-Jones TR, Moren F, Clarke SW. Improvement of pressurised aerosol deposition with Nebuhaler spacer device. Thorax 1984;39: 935-41.

10 Farrer M, Francis AJ, Pearce SJ. Morning serum cortisol concentrations after $2 \mathrm{mg}$ inhaled beclomethasone dipropionate in normal subjects: effect of a $750 \mathrm{ml}$ spacing dipropionate in normal subjects :

11 Löfdahl C-G, Mellstrand T, Svedmyr N. Glucocorticoids and asthma. Studies of resistance and systemic effects of glucocorticoids. Eur J Respir Dis 1984;65(suppl 136): 69-79. 